\title{
Correction to: Transcranial direct current stimulation (tDCS) in addition to walking training on walking, mobility, and reduction of falls in Parkinson's disease: study protocol for a randomized clinical trial
}

Lucas Rodrigues Nascimento 1,2, Ester Miyuki Nakamura-Palacios ${ }^{3}$, Augusto Boening ${ }^{1}$, Bárbara Naeme Lima Cordeiro ${ }^{1}$, Daniel Lyrio Cabral ${ }^{1}$, Alessandra Swarowsky ${ }^{4,5}$, Guilherme Peixoto Tinoco Arêas ${ }^{6}$, Wellingson Silva Paiva ${ }^{7}$ and Fernando Zanela da Silva Arêas ${ }^{1,3^{*}}$

Correction to: Trials 22, 647 (2021)

https://doi.org/10.1186/s13063-021-05603-z

Following the publication of the original article [1], we were notified that Bárbara Naeme Lima Cordeiro was missed from being mentioned on the 4th place in the authorship list.

Bárbara Naeme Lima Cordeiro has participated in the writing of the design of the protocol.

The original article has been corrected.

\section{Author details}

${ }^{1}$ Center of Health Sciences, Discipline of Physical Therapy, Universidade Federal do Espírito Santo (UFES), 1468 Marechal Campos Avenue, Maruípe, Vitória, ES 29043900, Brazil. 'NeuroGroup, Department of Physical Therapy, Universidade Federal de Minas Gerais (UFMG), Belo Horizonte, MG, Brazil. ${ }^{3}$ Laboratory of Cognitive Sciences and Neuropsychopharmacology, Department of Physiological Sciences, Universidade Federal do Espírito Santo (UFES), Vitória, ES, Brazil. ${ }^{4}$ Department of Physical Therapy, Universidade Estadual de Santa Catarina (UDESC), Florianópolis, SC, Brazil. ${ }^{5}$ Doctor of Physical Therapy Program, Advent Health University, Orlando, USA. ${ }^{6}$ Department of Human Physiology, Universidade Federal do Amazonas (UFAM), Manaus, AM, Brazil. ${ }^{7}$ Neurosurgery Division, Department of

The original article can be found online at https://doi.org/10.1186/s13063021-05603-z

*Correspondence: fernandozanela@hotmail.com

${ }^{1}$ Center of Health Sciences, Discipline of Physical Therapy, Universidade Federal do Espírito Santo (UFES), 1468 Marechal Campos Avenue, Maruípe, Vitória, ES 29043900, Brazil

${ }^{3}$ Laboratory of Cognitive Sciences and Neuropsychopharmacology,

Department of Physiological Sciences, Universidade Federal do Espírito Santo (UFES), Vitória, ES, Brazil
Neurology, Clinical Hospital, Faculty of Medicine, University of São Paulo, São Paulo, Brazil.

Published online: 18 October 2021

\section{Reference}

1. Nascimento et al. (2021) Transcranial direct current stimulation (tDCS) in addition to walking training on walking, mobility, and reduction of falls in Parkinson's disease: study protocol for a randomized clinical trial (2021) 22: 647 DOl: https://doi.org/10.1186/s13063-021-05603-z

(c) The Author(s). 2021 Open Access This article is licensed under a Creative Commons Attribution 4.0 International License, which permits use, sharing, adaptation, distribution and reproduction in any medium or format, as long as you give appropriate credit to the original author(s) and the source, provide a link to the Creative Commons licence, and indicate if changes were made. The images or other third party material in this article are included in the article's Creative Commons licence, unless indicated otherwise in a credit line to the material. If material is not included in the article's Creative Commons licence and your intended use is not permitted by statutory regulation or exceeds the permitted use, you will need to obtain permission directly from the copyright holder. To view a copy of this licence, visit http://creativecommons.org/licenses/by/4.0/ The Creative Commons Public Domain Dedication waiver (http://creativecommons.org/publicdomain/zero/1.0/) applies to the data made available in this article, unless otherwise stated in a credit line to the data. 